\title{
Aspectos relacionados ao afastamento de bancários por LER/DORT
}

\author{
Camilla Zavarizzi, Maria do Carmo Baracho de Alencar \\ Instituto Saúde e Sociedade, \\ Universidade Federal de São Paulo - UNIFESP, São Paulo, SP, Brasil
}

\begin{abstract}
Resumo: Objetivo: Investigar aspectos do afastamento do trabalho por LER/DORT de trabalhadores do setor bancário atendidos no Centro de Referência em Saúde do Trabalhador - CEREST de Santos, SP, e as relações desses afastamentos com organização e condições de trabalho. O estudo é exploratório, descritivo e qualitativo. Material e métodos: Foram analisados dados de prontuários de sujeitos atendidos no CEREST-Santos de janeiro a dezembro de 2010 com diagnósticos clínicos definidos e estabelecidos para transtornos dos tecidos moles (CID-10). Foram analisados 206 prontuários e, nesses, 17,9\% $(\mathrm{n}=37)$ dos sujeitos tinham transtornos dos tecidos moles, sendo oito do setor bancário. Posteriormente foram selecionados os sujeitos do setor bancário que estiveram ou estavam em situação de afastamento do trabalho. Foi elaborado um roteiro para as entrevistas semiestruturadas, contendo questões sobre: como era o trabalho do entrevistado, como ocorreu o adoecimento, sobre o afastamento, entre outras. As entrevistas foram gravadas e transcritas na íntegra para análise de conteúdo por categorias. Resultados: Participaram do estudo cinco sujeitos com idade entre 40 e 62 anos, sendo quatro do gênero feminino e um do gênero masculino. Em relação à escolaridade, todos possuíam ensino superior, sendo três com ensino completo e dois com ensino superior incompleto. Nos depoimentos foram encontrados aspectos como: ritmo intenso e repetitividade, humilhações em reuniões, exigências de metas, sintomas osteomusculares no trabalho, medo do desemprego, entre outros. Considerações finais: Alguns aspectos da organização e condições do trabalho bancário geravam desgaste e sofrimento e tiveram relação com os processos de adoecimento e afastamento do trabalho.
\end{abstract}

Palavras-chave: Licença Médica, Transtornos Traumáticos Cumulativos, Saúde do Trabalhador, Trabalho Bancário, Terapia Ocupacional.

\section{Aspects associated with sick leaves of bank clerks owing to RSI/WMSD}

\begin{abstract}
Objective: To investigate the aspects related to sick leaves of bank clerks, owing to repetitive strain injuries (RSI), attended at the Reference Center of Occupational Health - CEREST in the municipality of Santos, Sao Paulo state, Brazil, and their association with work organisation and conditions. Material and methods: Analyses of spreadsheets of subjects attended in the Reference Center of Occupational Health between January and December 2010, with clinical diagnoses related to soft tissue injuries from ICD-10. Two hundred six spreadsheets were analyzed, and $17.9 \%(n=37)$ of the subjects presented soft tissue injuries; eight of them were from the banking sector. Subsequently, the banking sector subjects that were or had been on sick leave were selected. A script was developed with semi-structured questions about the work environment, sickness process, and sick leave, among others. The interviews were recorded for integral verbatim transcription and categorical analyses. Results: Five subjects aged 40 to 62 participated in the study: four females and one male. Regarding schooling, all of them presented higher education level, three complete and two incomplete. Their statements revealed aspects such as intense rhythm and repetitiveness, humiliation in meetings, requirement for meeting targets, musculoskeletal symptoms at work,
\end{abstract}


and fear of losing the job, among others. Final considerations: Some aspect of work organisation and conditions generated distress and suffering, and were associated with the sickening and sick leave processes.

Keywords: Sick Leave, Repetitive Strain Injury, Occupational Health, Bank Working, Occupational Therapy.

\section{Introdução}

O trabalho tem um papel importante na constituição da identidade do sujeito (LANCMAN, 2004). O trabalho ocupa um espaço central na vida do sujeito e atua como o principal organizador dos modos de vida. Quando é rompido o vínculo laboral rompe-se também um lugar socialmente legitimado e reconhecido (RAMOS et al., 2010). O afastamento do trabalho é vivenciado como rompimento com o trabalho através do corpo, o corpo passa a ser dor e sofrimento, restrição, impotência e limitação (RAMOS; TITTONI; NARDI, 2008). Os mesmos autores citam que o rompimento com o trabalho devido a um adoecimento também poderia produzir alternativas e modos de trabalhar diferenciados, talvez mais "saudáveis" e inventivos, mas que isso raramente acontece, já que o afastamento traz um grande sofrimento para o trabalhador e é vivido em geral de forma solitária. Para Gaedke e Krug (2008), o afastamento do trabalho pode levar a demissões ou dificuldade de reingresso no mercado de trabalho, conflitos familiares, repercussóes nos assuntos financeiros que acabam desestabilizando o núcleo de convivência familiar e, consequentemente, também o convívio com o grupo social.

O trabalhador pode adoecer de diversas formas no mundo contemporâneo de trabalho, entre elas destacam-se as lesôes por esforços repetitivos - LER, ou distúrbios osteomusculares relacionados ao trabalho - DORT. Além da prevalência de acometimentos, a complexidade clínica das doenças também é um fator que configura as LER/DORT como um grande problema socioeconômico e de saúde pública da atualidade no Brasil (NEVES; NUNES, 2009). São afecçóes ocupacionais que expressam um dos sofrimentos advindos da relação do trabalhador com o trabalho (GHISLENI; MERLO, 2005). As Lesōes por Esforços Repetitivos - LER/Distúrbios Osteomusculares Relacionados ao Trabalho - DORT, para Couto, Nicoletti e Lech (1998), caracterizam-se por transtornos funcionais, mecânicos e lesóes de músculos, tendões, fáscias, nervos, entre outros, que resultam em fadiga, queda da performance no trabalho, incapacidade temporária, entre outros.

A LER/DORT não possui uma causa única para a sua ocorrência, ou seja, tem etiologia multifatorial, relaciona-se diretamente com as exigências das tarefas, ambientes físicos e com a organização do trabalho e podem estar envolvidos em sua gênese fatores psicológicos, biológicos e sociológicos (CHIAVEGATO FILHO; PEREIRA JUNIOR, 2004). A alta prevalência das LER/ DORT tem sido explicada por transformaçóes do trabalho, cuja organização tem se caracterizado pelo estabelecimento de metas, produtividade e aumento da competitividade de mercado, tendo o trabalhador que se adequar a essas características, sem serem levados em conta seus limites físicos e psicossociais (MAENO et al., 2006). Entre os aspectos que podem influenciar no surgimento de LER/DORT estão os aspectos da organizaçáo do trabalho.

A organização do trabalho perpassa todas as etapas do processo produtivo, prescrevendo normas e parâmetros que determinam quem vai fazer, o que vai ser feito, como, quando e com que equipamentos/ instrumentos, em que tempo, com que prazos, em que quantidade, com que qualidade, podendo contribuir para o bem-estar ou para a manifestação de sintomas que afetam a saúde (ABRAHÁO; TORRES, 2004). É definida por Dejours (1992) como: a divisão do trabalho, o conteúdo da tarefa, o sistema hierárquico, as modalidades de comando, as relaçóes de poder, as questóes de responsabilidade etc.

Quando se iniciou o uso intensivo de mão de obra assalariada em meados do século XVIII, na Inglaterra - época da Primeira Revolução Industrial - havia um intenso controle exercido sobre os trabalhadores de forma autoritária (MERLO; LAPIS, 2007). Segundo os mesmos autores, com a Segunda Revolução Industrial, no final do século XIX e início do século XX, surgiu a Organização Científica do Trabalho (OCT), a partir das observaçóes de Frederick Taylor de que boa parte dos problemas de baixa produtividade das fábricas devia-se à enorme variação de tempo de execução e de formas de executar o trabalho, pelos operários. Buscou-se simplificar as operaçōes, eliminar os movimentos desnecessários, lentos e ineficientes. Taylor impôs a todos os operários, sem distinção de características físicas, idade ou sexo, o parâmetro do modo operatório cientificamente estabelecido (DEJOURS, 1992). A partir de 1910, difundiu-se com os métodos e com as tecnologias utilizadas 
no Taylorismo a esteira rolante, criada por Henry Ford, reduzindo-se a necessidade de deslocamento e relacionamentos durante as operaçóes, na busca da diminuição dos tempos ociosos (MERLO; LAPIS, 2007).

Ocorre entâo por volta dos anos 1960 e $1970 \mathrm{a}$ reestruturação produtiva, devido aos conflitos sociais relacionados às formas tradicionais de organizaçáo do trabalho, ao acirramento da concorrência e às crises políticas e econômicas (ASSUNÇÃO, 2003). Nas premissas tayloristas-fordistas, o foco eram os aspectos físicos e fisiológicos para maior compreensão das capacidades humanas e, com a evolução da tecnologia, principalmente após a Segunda Guerra Mundial, entra a questấo da inteligência, que poderia ser útil para o processo produtivo, e agregaram-se também aspectos mentais e cognitivos (SZNELWAR; UCHIDA; LANCMAN, 2011).

Silva, Oliveira e Zambroni-de-Souza (2011) citam a existência de novas organizações de trabalho com velhas formas de controle, exigências e constrangimentos diversos, o que pode prejudicar a saúde do trabalhador. As organizaçóes estruturam-se de forma a conduzir o processo de acumulação, incentivando mudanças que propiciem aumento de produtividade e isso pode explodir em conflito, já que a realidade, desejo e intenção do trabalhador são diferentes dos desejos, realidades, e intençóes da empresa (CASTELHANO, 2005).

A categoria profissional dos bancários foi uma das que mais teve alteraçáo na sua forma de executar o trabalho com as mudanças decorrentes da reestruturação produtiva (SOARES; VILLELA, 2012). Segundo Carrijo e Navarro (2009), o setor financeiro brasileiro foi pioneiro em adotar a automação e informatizar-se na década de 1990, o que gerou profundas mudanças no processo de trabalho bancário. $\mathrm{O}$ processo de trabalho bancário no Brasil pode ser dividido em três etapas: na primeira, que compreende até a década de 1960, o trabalhador exercia o controle sobre a execução do seu trabalho; na segunda, até a década de 1980, há o predomínio do padrão taylorista-fordista, baseado em rotinas predefinidas, desqualificando-se o trabalho do bancário à medida que o conhecimento exigido na fase anterior foi descartado; a terceira fase, a partir da década de 1980, foi marcada pela difusão do uso de computadores no ambiente do trabalho bancário (SILVA; NAVARRO, 2012).

$O$ processo de automação e informatizaçáo do trabalho bancário acarretou mudanças na organização, nas condições e nas relaçôes de trabalho, resultando em intensificação do ritmo, sobrecarga de tarefas, diminuição de postos de trabalho e aumento da pressão e controle sobre os trabalhadores (SILVA; NAVARRO, 2012). Para os mesmos autores, a partir do processo de reestruturação produtiva, as mudanças ocorridas, além de terem afetado a maneira de ser do trabalho bancário, também afetaram a saúde dos trabalhadores.

A automação na categoria bancária introduziu novas tarefas ligadas à informática, aumentando o controle e a mecanização do processo de trabalho (GRAVINA; ROCHA, 2006). Esse processo de informatização em empresas do setor de serviços foi acompanhado de uma significativa expansão, com a introdução de novos produtos, de tecnologias mais avançadas e de melhorias dos sistemas de informação (SZNELWAR; MASSETI, 2002). O trabalho, teoricamente, seria mais fácil e mais produtivo, no entanto, os mesmos autores citam que não há uma relação direta entre produzir usando um sistema informatizado e obter melhorias no trabalhar. Ao contrário, ao invés de liberar o trabalhador das tarefas repetitivas, a ampliaçấo do conteúdo das atividades, para o bancário, resultou na intensificaçáo e aceleração do ritmo de trabalho, pela exigência do aumento da produtividade (MUROFUSE; MARZIALE, 2001). Atualmente, os bancos se concentram na realização de negócios como, por exemplo, a administração de cartóes de crédito, seguros, previdência privada, títulos de capitalização e vários outros produtos, incorporando ao trabalho bancário o papel de venda de produtos e de consultoria financeira (GRAVINA; ROCHA, 2006).

Para Paparelli (2011), a organização do trabalho bancário foi geradora de competitividade e sobrecarga, contribuindo para o adoecimento físico e mental. Segundo o sindicato dos bancários de Brasília (SINDICATO..., 2011), a categoria bancária consta nas estatísticas como uma das maiores vítimas de acidentes de trabalho envolvendo distúrbios osteomusculares relacionados ao trabalho - DORT. Segundo o Anuário Estatístico da Previdência Social (BRASIL, 2011), no ano de 2011, o subsetor com maior participação nas doenças de trabalho foi o de "atividades financeiras" (Banco Central, bancos múltiplos, Caixas Econômicas, entre outros) da Classificação Nacional de Atividades Econômicas (CNAE), com 13\% do total; dentre os 50 códigos de CID com maior incidência, as doenças do trabalho mais incidentes foram lesóes no ombro (M75), sinovite e tenossinovite (M65) e dorsalgia (M54), com 20,2\%, 14,2\% e 7,7\%, do total, respectivamente. Para Bruno (2011), a pressão para atingir as metas é uma das principais causas de adoecimento, tanto pelo esforço repetitivo, como pelo desgaste mental. 
Considerando que o trabalho em condiçóes precárias pode levar o trabalhador ao adoecimento e afastamento, causar rupturas em papéis sociais e ocasionar limitaçóes funcionais no cotidiano de vida, a Terapia Ocupacional traz contribuiçóes importantes visando à prevenção de LER/DORT $\mathrm{e}$ em processos de reabilitação e retorno ao trabalho.

A Terapia Ocupacional atualmente tem uma visão mais crítica frente ao sujeito e à organizaçáo social na qual ele está inserido, intervindo sobre a ação do trabalhador e seu trabalho contextualizado no ambiente e na cultura organizacional (WATANABE; NICOLAU, 2001). Diversos recursos tradicionais dos terapeutas ocupacionais na área de saúde e trabalho ganham uma nova dimensão e aplicação como, por exemplo, a análise de atividades, que deixa de ser centrada no fazer individual e passa a abranger a compreensão de situações de trabalho tanto no âmbito organizacional quanto no que diz respeito às condições de trabalho (LANCMAN; GHIRARDI, 2002). As práticas desse profissional compreendem o indivíduo de forma global e consideram os aspectos subjetivos vividos no trabalho, essenciais na busca de processos de transformação de situaçôes do trabalho (LANCMAN, 2004).

Os terapeutas ocupacionais têm sido cada vez mais solicitados a atenderem sobretudo portadores de LER/DORT em serviços públicos, serviços escola, Centros de Referência em Saúde do Trabalhador - CERESTs e clínicas privadas (LANCMAN; GHIRARD, 2002). Nos CERESTs, as ações são voltadas para a assistência, a vigilância e a educação para a saúde, contando com uma equipe multidisciplinar na qual o terapeuta ocupacional vem ampliando sua intervençáo, realizando desde avaliaçôes e intervençôes diretas em situaçôes de trabalho (através das vigilâncias), até atendimentos individuais e/ou grupais, ginástica terapêutica chinesa e oficinas de Terapia Ocupacional (GUTTERRES; BARFKNECHT, 2005).

O objetivo deste estudo foi investigar aspectos do afastamento do trabalho por LER/DORT de trabalhadores do setor bancário atendidos no Centro de Referência em Saúde do Trabalhador - CEREST da cidade de Santos, SP, e suas relaçóes com a organização e condiçóes de trabalho.

\section{Materiais e métodos}

O estudo é qualitativo, exploratório e descritivo. Contém duas etapas. Na primeira foi obtida uma listagem com o número de prontuários abertos de sujeitos atendidos no CEREST-Santos no período de
1 de janeiro de 2010 a 31 de dezembro de 2010 . O levantamento dos dados foi norteado por um roteiro para registro, contendo: gênero, idade, escolaridade, categoria profissional, diagnósticos clínicos, causa do afastamento, tempo de afastamento, entre outros. Os diagnósticos clínicos foram agrupados e categorizados conforme a Classificação Internacional de Doenças CID-10, sendo o critério de seleção para este estudo os sujeitos da listagem acima que apresentaram diagnósticos clínicos relacionados aos transtornos dos tecidos moles (M60 a M79), do setor bancário, em situação de afastamento do trabalho ou que vivenciaram o processo de afastamento do trabalho relacionado às afecçóes citadas. Dos 206 prontuários analisados, $17,9 \%(\mathrm{n}=37)$ apresentavam diagnóstico clínico relacionado a transtornos dos tecidos moles, sendo que desses sujeitos, oito eram do setor bancário. Foram realizados contatos telefônicos e agendamentos para entrevistas. Elaborou-se um roteiro para as entrevistas contendo questôes semiestruturadas sobre: como era o trabalho do sujeito, quais dificuldades encontrava no trabalho, como se sentia no trabalho, como tinha ocorrido o adoecimento, sobre o afastamento, entre outras. As entrevistas foram gravadas e transcritas na íntegra para análise de conteúdo por categorias (BARDIN, 2010). Para essa autora, a técnica de análise de conteúdo pressupóe algumas etapas, como: pré-análise; exploração do material ou codificação; tratamento dos resultados, inferência e interpretação. Primeiramente ocorreu uma leitura flutuante dos depoimentos e, posteriormente, a análise dos dados. Buscou-se nas análises a determinação de unidades de registro, para posterior definiçáo das categorias.

Este projeto foi aprovado pelo Comitê de Ética da Universidade Federal de Sáo Paulo; o Termo de Consentimento Livre e Esclarecido - TCLE também foi apresentado e assinado pelos sujeitos do estudo.

\section{Resultados e discussão}

Participaram deste estudo cinco $(\mathrm{n}=5)$ sujeitos. $\mathrm{Na}$ Tabela 1 estão demonstrados os dados demográficos e os relacionados ao trabalho.

Dos sujeitos, três estavam afastados do trabalho - a maioria dos entrevistados estava em idade produtiva. Conforme observado na Tabela 1, a maioria dos trabalhadores era do gênero feminino e possuía ensino superior completo. Os entrevistados tinham diferentes cargos, havendo diferenças em algumas tarefas como, por exemplo: caixas bancários realizam recebimento de pagamentos, saques, entre outros; gerentes fazem intermediaçóes bancárias entre o cliente e os serviços do banco; e subgerentes realizam 
Tabela 1. Dados demográficos e relacionados ao trabalho dos sujeitos entrevistados.

\begin{tabular}{ll}
\hline \multicolumn{1}{c}{ Dados } & \multicolumn{1}{c}{$\quad$ (N = 5) } \\
\hline Idade & De 40 a 62 anos \\
\hline Gênero & Feminino $(\mathrm{n}=4)$ \\
& Masculino $(\mathrm{n}=1)$ \\
\hline Escolaridade & Ensino superior incompleto $(\mathrm{n}=2)$ \\
& Ensino superior completo $(\mathrm{n}=3)$ \\
\hline Profissão & Caixa $(\mathrm{n}=2)$ \\
& Gerente $(\mathrm{n}=2)$ \\
& Subgerente $(\mathrm{n}=1)$ \\
\hline Tempo de atuação no setor bancário & Inferior a 10 anos $(\mathrm{n}=1)$ \\
& Superior a 10 anos $(\mathrm{n}=4)$ \\
\hline
\end{tabular}

funçôes de gerente, como auxiliares, entre outras. Mesmo havendo cargos diferentes, algumas exigências eram semelhantes como, por exemplo, a venda de produtos bancários.

As afeç̧ôes que acometeram os sujeitos foram: sinovites e tenossinovites $(\mathrm{n}=2)$, síndrome do manguito rotador $(n=2)$, bursite de ombro $(n=1)$, tendinite calcificada $(\mathrm{n}=1)$, lesões não específicas do ombro $(\mathrm{n}=2)$, sendo que alguns sujeitos apresentaram mais de uma afecção estabelecida entre transtornos dos tecidos moles. As regiōes mais acometidas entre os sujeitos foram: ombros e punhos, dedos e máos.

\subsection{Ritmo intenso de trabalho e supervisão rígida}

As exigências para o cumprimento de metas impunham muitas vezes um ritmo intenso de trabalho, evidenciado junto aos caixas bancários - em alguns casos havia sistemas eletrônicos que controlavam o tempo que o trabalhador levava para atender o cliente.

"[...] no nosso caixa era assim, tem três luzinhas, uma verde, uma amarela e uma vermelha, porque não podia passar, você tem que tá sempre na verde, se você passar pro amarelo, o teu chefe ele já chega lá [...], gritando, dizendo que o negócio tá ficando feio..." (52 anos, gênero feminino, caixa bancária).

"[...] olha o tempo da fila, falta um minuto, vai estourar, vai estourar a papeleta... a gente vivia trabalhando assim" (47 anos, gênero feminino, caixa bancária).

Havia pressão por parte dos supervisores sobre o controle de tempo durante o atendimento de clientes que intensificava o ritmo de trabalho e gerava desgaste, pois nem sempre em atendimentos ao público é possível prever as demandas e acelerar os processos. O ritmo acelerado de trabalho, a repetitividade de movimentos e a insuficiência de pausas muitas vezes fazem o trabalhador ir além de suas capacidades físicas e podem favorecer o desgaste físico e mental (ALENCAR; OTA, 2011). Para os mesmos autores é sempre necessária certa flexibilidade em relação ao ritmo de trabalho, para evitar fadiga e tensão muscular.

\subsection{Exigências para o cumprimento de metas}

Os trabalhadores bancários, tanto os caixas quanto os subgerentes e gerentes, além de suas tarefas principais, tinham de vender produtos bancários, como cartôes de crédito, seguros, entre outros. Para a venda desses produtos, eram estabelecidas metas consideradas inviáveis pelos trabalhadores, pois sempre estavam aumentando.

"[...] eles nunca colocam metas que você possa cumprir, que é possivel cumprir [...], tudo é por cima de muita luta" (40 anos, gênero feminino, subgerente).

"[...] se num mês a gente tem de fazer uma venda de 1.500 pontos, e aí a gente bate e a agência consegue... ai eles botam para 1.800" (47 anos, gênero feminino, gerente de negócios).

Em alguns depoimentos foi constatado que mesmo que o sujeito cumprisse uma determinada meta essa não se mantinha, sendo substituída por outra mais elevada. Ocorre que é muito raro o estabelecimento de metas de fácil cumprimento, normalmente os trabalhadores bancários recebem metas de produção incompatíveis com sua capacidade, assim, principalmente o trabalhador acometido por LER/DORT tem dificuldades para cumprir as metas estabelecidas pelos bancos (GRAVINA; ROCHA, 2006). Paparelli (2011) cita que a instituição bancária 
afirma que a pressão para o aumento da produtividade vem do "mercado", não se responsabilizando pela busca do incremento de lucratividade da empresa. Segundo essa autora, são concedidos aos trabalhadores prêmios por produtividade e implantadas políticas de individualização dos salários vinculados ao cumprimento de metas de produtividade. Para Bruno (2011), as metas devem ser estabelecidas de forma coletiva, pelo conjunto dos trabalhadores, e devem ser levados em conta porte da unidade, localizaçáo, número de funcionários, perfil econômico da região, entre outros. É preciso haver espaços de diálogo, nos quais os trabalhadores possam discutir sobre as metas.

As exigências de venda de produtos bancários impostas, incorporadas às funçôes tradicionais dos trabalhadores bancários, traziam desgaste.

"[...] pro banco você tem de insistir, você tem de ficar em cima da pessoa até ela comprar... e você faz uma coisa que você não gosta, mas você tem de fazer" (62 anos, gênero feminino, subgerente).

\section{"[...] não tem como você vender naturalmente, você tem de empurrar aquilo pro cliente, às vezes o produto nem é tão bom, e a gente sabe que às vezes é uma enganação, mas você não vai falar isso pro cliente" (62 idade, gênero feminino, subgerente).}

Para alguns sujeitos, alguns produtos não tinham utilidade e ter de insistir sobre determinada venda junto ao cliente, de algo que o cliente não está necessitando, ou de produto considerado "ruim", representava aparentemente infração de questóes éticas e morais. Com a comercializaçáo de produtos bancários, identificou-se descaracterização do trabalho, que levou ao surgimento de um ambiente de trabalho competitivo e sem padróes éticos no qual os trabalhadores tiveram de superar valores pessoais para vender algo que nem eles mesmos comprariam (SANTOS JÚNIOR; MENDES; ARAUJO, 2009). Pressionados a agir contrariamente a seus valores éticos e morais para alcançar metas exigidas, os trabalhadores bancários vêm sendo submetidos a medo, humilhaçóes, injustiças e até ilegalidades por parte dos bancos (PAPARELLI, 2011).

\subsection{Horas extras}

Para atenderem às exigências do cumprimento de metas, era muitas vezes necessário estender a jornada de trabalho com horas extras.

"[...] O trabalho, que é de oito horas ou seis horas, não é o suficiente, você tem de trabalhar mais e mais" (49 anos, gênero masculino, gerente de negócios).

"[...] são seis horas direto, mas na verdade a gente trabalha muito mais. Aquela ilusão de ir trabalhar no banco pra entrar às $10 \mathrm{~h}$ e sair às 16h é tudo mentira" (62 anos, gênero feminino, subgerente).

As demandas do trabalho exigiam que os trabalhadores fossem flexíveis quanto à realização de horas extras, com atividades como reunióes, treinamentos, entre outras, possíveis de serem realizadas, em geral, fora do horário do funcionamento do banco para o público. A introdução da automação e a redução dos postos de trabalho intensificou o volume de trabalho e passou a exigir do trabalhador bancário uma concepção mais generalista de suas tarefas e habilidades para lidar com situaçóes imprevistas, e com isso tem-se o desrespeito da duração da jornada de trabalho (SILVA; NAVARRO, 2012). Em estudo de Murofuse e Marziale (2001), as exigências de realização de horas extras eram necessárias pelo volume de trabalho, que variava ao longo do mês, insuficiência do número de funcionários e devido à característica do trabalho bancário, no qual as metas a serem cumpridas começam e terminam no mesmo expediente, sendo necessário trabalhar além da carga horária normal.

\subsection{Presença de sintomas osteomusculares no trabalho}

Foram encontrados sintomas osteomusculares, durante a jornada de trabalho, em unanimidade junto aos sujeitos entrevistados:

"[...] trabalhei com dor! E medicação... tudo... não tinha jeito" (40 anos, gênero feminino, subgerente).

"[...] eu tava trabalhando à base de remédios..." (47 anos, gênero feminino, caixa bancário).

Os trabalhadores, mesmo sentindo sintomas osteomusculares, se sujeitavam às exigências do trabalho e minimizavam ou contornavam os sintomas muitas vezes com medicação. Executar tarefas com exigências físicas e presença de sintomas dolorosos pode favorecer o agravamento do quadro clínico e levar ao afastamento do trabalho (ALENCAR; MONTREZOR, 2010). Uma das principais formas encontradas para amenizar a dor, muitas vezes em um estado já crônico da doença, e dar conta de continuar no trabalho é o uso contínuo de medicação, o que 
pode acabar se transformando em dependência física e psíquica (GAEDKE; KRUG, 2008).

Houve situaçóes em que os sintomas no trabalho causavam também irritabilidade, impaciência, desânimo, entre outros, afetando o desempenho no trabalho.

\section{"[...] Era desagradável trabalhar sentindo dore vocêfica irritada, às vezes é meio brusca com as pessoas, porque você tá com aquela dor que tá te incomodando..." (62 anos, gênero feminino, subgerente).}

"[...] A dor, ela vai te deixando muito desanimada, porque você quer fazer as coisas e não consegue" (47 anos, gênero feminino, caixa bancária).

Em pesquisa de Murofuse e Marziale (2001) verificou-se que as mudanças em decorrência da LER não relacionavam-se apenas ao aspecto físico, mas também a aspectos emocionais, como angústias e preocupaçôes, ocasionando a piora do quadro clínico.

\subsection{Invisibilidade da doença}

Ter sintomas osteomusculares e eles não serem "considerados" pelos pares e supervisores durante a jornada de trabalho foi um aspecto destacado por alguns trabalhadores:

"[...] a situação é horrivel, você tem algo que ninguém vê, só você tá sentindo a dor" (52 anos, gênero feminino, caixa bancária).

"[...] não é aparente, entendeu? Então a pessoa näo entende, acham que é frescura, muitas pessoas acham que não tem nada e que é uma maneira d'eu tá encostada pelo INSS, sabe?" (40 anos, gênero feminino, subgerente).

Os trabalhadores entrevistados se sentiam constrangidos e injustiçados em situaçóes em que os sintomas osteomusculares referidos não eram considerados verdadeiros. É comum a ideia que a sociedade tem de que os sujeitos acometidos por LER/ DORT não querem trabalhar, e há um julgamento de que eles possam estar fingindo o adoecimento para se afastarem (GAEDKE; KRUG, 2008). Trabalhadores bancários com LER/DORT foram considerados suspeitos, como alguém que almeja obter benefícios por estar afastado do trabalho (SZNELWAR; MASSETI, 2002; MUROFUSE; MARZIALE, 2001). Para Alencar e Ota (2011), as queixas dolorosas sem diagnóstico clínico também geram dúvidas e desconfianças nos peritos. Ramos et al. (2010) citam que a LER/DORT é invisível porque não apresenta sinais externos. Existem algumas dificuldades em relação ao diagnóstico da LER/DORT e é preciso acreditar no discurso do paciente, já que nos estágios iniciais dos distúrbios essas são as informações mais relevantes (GAEDKE; KRUG, 2008).

\subsection{Humilhações em reuniões}

Alguns trabalhadores do setor bancário relataram que em reuniôes alguns gerentes expunham os resultados de cada trabalhador e faziam cobranças para uma melhor eficácia, expondo o colega a situaçóes muitas vezes constrangedoras.

"[...] e na frente de todo mundo apontava [supervisor], você cumpriu, você não cumpriu, e você ficava constrangido e com vergonha, né, porque fulano cumpriu e tu não cumpriu, dá impressão que tu trabalhou menos que o outro" (40 anos, gênero feminino, subgerente).

"[...] as reuniōes, as cobranças eram na frente de todo mundo, eles falavam de cada um, era desagradável, principalmente quando você era questionado na frente dos outros" (62 anos, gênero feminino, subgerente).

As reunióes realizadas pelos supervisores deixavam os trabalhadores que não conseguiam atingir as metas estipuladas pela gestão muitas vezes constrangidos perante os demais colegas, pois expunham a eficácia do trabalhador. Há a questão da ridicularização pela gerência quando os trabalhadores não alcançam as metas, com a exposição do fracasso diante dos colegas durante as reuniôes das equipes (SANTOS JÚNIOR; MENDES; ARAÚJO, 2009). Isso pode ser considerado assédio moral. O assédio moral pode ser expresso por humilhaçôes, ameaças, abusos de poder, agressóes verbais, sabotagens de instrumentos de trabalho e injúrias, através de palavras, gestos, atitudes, entre outros (SOARES; VILLELA, 2012). Os mesmos autores citam que o assédio moral causa sofrimento e faz adoecer, pois minimiza, desvaloriza, atinge a integridade do trabalhador, desgastando-o moral e psicologicamente, colocando em risco o emprego e a identidade do sujeito, podendo levá-lo a somatizações que desestabilizam sua saúde física e mental.

\subsection{Medo do desemprego}

O medo do desemprego foi relatado por todos os trabalhadores entrevistados:

"[...] e eu estava sob atestado médico, tentando trabalhar mesmo que já acometido do problema, 
pra não perder o emprego" (49 anos, gênero masculino, gerente de negócios).

"[...] se eu não fizer o que o banco tava pedindo, eu ia ser mandado embora e eu não podia perder meu emprego, então tinha de acompanhar o ritmo do banco" (47 anos, gênero feminino, caixa bancária).

O medo de perder o emprego foi evidenciado pela maioria, sendo um dos motivos pelos quais os trabalhadores se submetiam a situaçôes críticas no trabalho e, supostamente, à convivência com as dores. O medo do desemprego torna-se um poderoso instrumento de manipulação dos trabalhadores, na medida que o sujeito intensifica sua energia e volta todas as suas forças para a empresa, aumentando a produtividade (CASTELHANO, 2005). Para o mesmo autor, o trabalhador tem medo de perder o prestígio, de fracassar, de perder seu posto. Para Dejours (2006), os trabalhadores inibem sua inconformidade por medo de perder o emprego ou por vergonha de demonstrar que sofrem e de reclamar de condiçóes inumanas de trabalho.

A ausência do emprego está relacionada à ausência de um papel social que o sujeito exerce na sociedade (RAMOS et al., 2010). Ter um emprego (trabalho) remete a um status econômico, de acordo com o salário. Dejours (1992) cita que o salário contém numerosas significações concretas: de sustentar a família, pagar dívidas, mas também tem significaçōes abstratas, na medida em que o salário contém sonhos e projetos.

\subsection{Competição com trabalhadores mais jovens}

A presença de funcionários mais jovens gerava certa tensão para alguns sujeitos, pela percepçáo de que eles teriam maior disposição para empenhar-se no trabalho e cumprir as exigências das metas, aumentando a competiçấo junto aos mais antigos.

"[...] eles acham que as pessoas mais novas vão entrar com mais vontade, vão vender mais" (47 anos, gênero feminino, caixa bancária).

\section{"[...] eu competia com os jovens, então você tem de mostrar serviço, no banco é aquela cobrança de produção" (62 anos, gênero feminino, subgerente).}

Essa percepção de que os trabalhadores mais jovens teriam mais facilidade de dar conta da produçáo exigida foi um dos aspectos abordados pelos sujeitos entrevistados e que contribuía para o aumento do clima de competitividade. Alguns trabalhadores se viam obrigados a superar seu desempenho para atingir as metas estipuladas, e junto a colegas mais jovens. A contratação de funcionários mais novos, assim como de uma grande massa de estagiários, tornou mais acirrada a concorrência entre os trabalhadores (CARRIJO; NAVARRO, 2009). A organização do trabalho bancário, geradora de competitividade e sobrecarga, é um elemento fundamental no processo de adoecimento físico e mental dos trabalhadores (PAPARELLI, 2011).

\subsection{Sentimento de inutilidade}

Por estarem adoecidos e alguns em situaçáo de afastamento do trabalho, eles passaram a sentirem-se inúteis:

"[...] porque quando vocêfica doente, você é uma porcaria, você não serve pra mais nada" (52 anos, gênero feminino, caixa bancária).

"[...] vocêpensa: agora como vai ser minha vida daqui em diante, você deixou de ser útil" (62 anos, gênero feminino, subgerente).

O "ser útil", de acordo com alguns depoimentos, estava aparentemente relacionado à atividade laborativa, logo, se não era possível trabalhar, deixava-se de ser útil tanto no ambiente de trabalho quanto socialmente. A percepção do desperdício de anos de vida por conta do adoecimento, discriminaçáo e rejeição no mundo do trabalho, sensação de não mais ser reconhecido dentro de seu próprio ambiente de trabalho, o atestado público de declínio profissional, o descrédito quanto à condição de enfermo e o desengano quanto à possibilidade de melhora fazem parte da percepção de si do sujeito afastado (NEVES; NUNES, 2009). A doença desperta nos trabalhadores sentimentos de inutilidade, ociosidade, acarretando, muitas vezes, quadros depressivos e de profundo desânimo, principalmente em relação ao desconhecimento que as outras pessoas têm a respeito da doença, além da convivência diária com a dor e a dependência da medicação (GAEDKE; KRUG, 2008).

\section{Considerações finais}

Os depoimentos dos trabalhadores bancários entrevistados demonstraram aspectos críticos da organização e condiçóes de trabalho que influenciaram nos processos de adoecimento, como: realização de horas extras, ritmo acelerado, exigência de metas, entre outros que geravam desgaste e, para 
alguns, sofrimento. Situaçóes geradoras de desgaste mental podem gerar sofrimento psíquico, pondo em risco a saúde mental do trabalhador, dependendo das estratégias defensivas utilizadas.

Entre os aspectos que muitas vezes levavam ao desgaste e sofrimento entre os trabalhadores: convivência com a dor, invisibilidade da doença, pressão para o cumprimento de metas, as quais os trabalhadores julgavam muitas vezes inalcançáveis, entre outros. O caráter crônico e incapacitante da LER/DORT pode gerar sofrimento aos trabalhadores, na medida em que as limitaçôes funcionais podem afetar diversos papéis sociais no cotidiano de vida, sendo o de trabalhador um desses papéis.

Os trabalhadores suportavam dores osteomusculares durante a jornada de trabalho, situação que colocava em risco o agravamento do quadro clínico. O medo de perder o emprego e o que isso agrega na vida do trabalhador pode ter sido um aspecto que fez com que os trabalhadores se sujeitassem às situações de desgaste físico e mental no trabalho. Os modos de organizaçáo do trabalho, com características de diminuição de custos para as empresas, e lógicas que visam à alta produção e lucratividade sem levar em consideração aspectos subjetivos dos trabalhadores, em geral acabam por aumentar os riscos de agravos à saúde do trabalhador tanto no aspecto físico quanto mental.

Ressalta-se que, diante do tema saúde e trabalho, estáo sendo consideradas de extrema importância açôes de prevenção e vigilância de situaçôes que podem gerar agravos à saúde no trabalho, sendo importantes as contribuiçóes de terapeutas ocupacionais com experiência nessa área. Além disso, em casos de adoecimento e afastamento do trabalho, o profissional terapeuta ocupacional pode auxiliar nos processos de reabilitação e retorno ao trabalho.

Estudos futuros devem ser realizados para aprofundar os resultados obtidos e para contribuir com análises que visem à prevenção de LER/DORT em trabalhadores do setor bancário.

\section{Referências}

ABRAHÃO, J. I.; TORRES, C. C. T. Entre a organização do trabalho e o sofrimento: o papel de mediação da atividade. Revista Produção, São Paulo, v. 14, n. 3, p. 67-76, 2004.

ALENCAR, M. C. B.; MONTREZOR, J. B. M. Aspectos da organização do trabalho e os distúrbios osteomusculares: um estudo com trabalhadores em instituiçôes de longa permanência de idosos. Revista de Terapia Ocupacional da USP, São Paulo, v. 21, n. 1, p. 15-22, 2010.

ALENCAR, M. C. B.; OTA, N. H. O afastamento do trabalho por LER/DORT, repercussão na saúde mental.
Revista de Terapia Ocupacional da USP, São Paulo, v. 22, n. 1, p. 60-67, 2011.

ASSUNÇÃO, A. A. Uma contribuição ao debate sobre as relaçôes saúde e trabalho. Ciência \& Saúde Coletiva, São Paulo, v. 8, n. 4, p. 1005-1018, 2003. http://dx.doi. org/10.1590/S1413-81232003000400022

BARDIN, L. Análise de conteúdo. Lisboa: Ediçōes 70, 2010.

BRASIL. Ministério da Previdência Social. Anuário Estatístico da Previdência Social 2011, Brasília, v. 20, p. 1-888, 2011. Disponível em: <http://www.mpas.gov. br/arquivos/office/1_121023-162858-947.pdf>. Acesso em: 30 abr. 2013.

BRUNO, W. P. Bancários não são máquinas. In: SZNELWAR, L. (Org.). Saúde dos bancários. São Paulo: Gráfica Atitude, 2011. p. 21-31.

CARRIJO, D. C. M.; NAVARRO, V. L. LER e planos de demissão voluntária: trajetórias de dor e sofrimento entre bancários. Cadernos de Psicologia Social do Trabalho, São Paulo, v. 12, n. 2, p. 157-171, 2009. http://dx.doi. org/10.11606/issn.1981-0490.v12i2p157-171

CASTELHANO, L. M. O medo do desemprego e a(s) nova(s) organizaçôes de trabalho. Psicologia \& Sociedade, Porto Alegre, v. 17, n. 1, p. 17-28, 2005.

CHIAVEGATO FILHO, L. G.; PEREIRA JUNIOR, A. LER/DORT: multifatorialidade etiológica e modelos explicativos. Interface: Comunicação, Saúde, Educação, Botucatu, v. 8, n. 14, p. 149-62, 2004

COUTO, H. A.; NICOLETTI, S. J.; LECH, O. Como gerenciar a questão das LER/DORT: lesóes por esforços repetitivos, distúrbios osteomusculares relacionados ao trabalho. Belo Horizonte: Ergo, 1998.

DEJOURS, C. A loucura do trabalho: estudo de psicopatologia do trabalho. São Paulo: Cortez Oboré, 1992.

DEJOURS,C. A banalização da injustiça social. Rio de Janeiro: FGV, 2006.

GAEDKE, M. A.; KRUG, S. B. Quem eu sou? A identidade de trabalhadoras portadoras de LER/DORT. Revista Textos \& Contextos, Porto Alegre, v. 7, n. 1, p. 120-137, 2008.

GHISlENI, A. P.; MERlO, A. R. C. Trabalhador contemporâneo e patologias por hipersolicitação. Psicologia: Reflexão e Crítica, Porto Alegre, v. 18, n. 2, p. 171-176, 2005. http://dx.doi.org/10.1590/S0102-79722005000200004

GRAVINA, M. E. R.; ROCHA, L. E. Lesões por Esforços Repetitivos em bancários: reflexôes sobre o retorno ao trabalho. Cadernos de Psicologia Social do Trabalho, São Paulo, v. 9, n. 2, p. 41-55, 2006. http://dx.doi.org/10.11606/ issn.1981-0490.v9i2p41-55

GUTTERRES, C. M. F.; BARFKNECHT, K. S. Terapia Ocupacional nas LER/DORT. Boletim Saúde, Porto Alegre, v. 19, n. 1, p. 85-90, 2005.

LANCMAN, S. Construção de Novas Teorias e Práticas em Terapia Ocupacional, Saúde e Trabalho. In: LANCMAN, S. (Org.). Saúde, Trabalho e Terapia Ocupacional. São Paulo: Roca, 2004. p. 71-83. 
LANCMAN, S.; GHIRARDI, M. I. G. Pensando novas práticas em terapia ocupacional, saúde e trabalho. Revista de Terapia Ocupacional da USP, São Paulo, v. 13, n. 2, p. 44-50, 2002.

MAENO, M. et al. LER/DORT: protocolos de atenção integrada à saúde do trabalhador de complexidade diferenciada. Brasília: Ministério da Saúde, 2006. Disponível em: <http://bvsms.saude.gov.br/bvs/ publicacoes/protocolo_ler_dort.pdf>. Acesso em: 19 abr. 2013.

MERLO, A. R. C.; LAPIS, N. L. A saúde e os processos de trabalho no capitalismo: reflexóes na interface da Psicodinâmica do Trabalho e da Sociologia do Trabalho. Psicologia \& Sociedade, Porto Alegre, v. 19, n. 1, p. 61-68, 2007. http://dx.doi.org/10.1590/ S0102-71822007000100009

MUROFUSE, N. T.; MARZIALE, M. H. P. Mudanças no trabalho e na vida de bancários portadores de lesões por esforços repetitivos: LER. Revista Latino-americana de Enfermagem, Ribeirão Preto, v. 9, n. 4, p. 19-25, 2001.

NEVES, R. F.; NUNES, M. O. Incapacidade, cotidiano e subjetividade: a narrativa de trabalhadores com LER/ DORT. Interface: Comunicação, Saúde, Educação, Botucatu, v. 13, n. 30, p. 55-66, 2009.

PAPARELLI, R. Grupos de enfrentamento do desgaste mental no trabalho bancário: discutindo saúde mental do trabalhador no sindicato. Revista Brasileira de Saúde Ocupacional, São Paulo, v. 36, n. 123, p. 139-146, 2011. http://dx.doi.org/10.1590/S0303-76572011000100013

RAMOS, M. Z. et al. Trabalho, adoecimento e histórias de vida em trabalhadoras da indústria calçadista. Estudos de Psicologia, Natal, v. 15, n. 2, p. 207-215, 2010.

RAMOS, M. Z.; TITTONI, J.; NARDI, H. C. A experiência de afastamento do trabalho por adoecimento vivenciada como processo de ruptura ou continuidade nos modos de viver. Cadernos de Psicologia Social do Trabalho, São Paulo, v. 11, n. 2, p. 209-221, 2008. http://dx.doi. org/10.11606/issn.1981-0490.v11i2p209-221
SANTOS JÚNIOR, A. V.; MENDES, A. M.; ARAUJO, L. K. R. Experiência em Clínica do Trabalho com bancários adoecidos por LER/DORT. Psicologia: Ciência e Profissão, Brasília, v. 29, n. 3, p. 614-625, 2009. http:// dx.doi.org/10.1590/S1414-98932009000300014

SILVA, E. F.; OLIVEIRA, K. K. M.; ZAMBRONI-DESOUZA, P. C. Saúde mental do trabalhador: o assédio moral praticado contra trabalhadores com LER/DORT. Revista Brasileira de Saúde Ocupacional, São Paulo, v. 36, n. 123, p. 56-70, 2011.

SILVA, J. L. NAVARRO, V. L. Organização do trabalho e saúde de trabalhadores bancários. Revista Latino-Americana de Enfermagem, Ribeirão Preto, v. 20, n. 2, p. 226-234, 2012. http://dx.doi.org/10.1590/ S0104-11692012000200003

SINDICATO DOS BANCÁRIOS DE BRASÍLIA. Bancários são as maiores vítimas de doenças osteomusculares e do tecido conjuntivo. Brasília, 2011. Disponível em: <http://www.bancariosdf.com.br/site/ caixa/bancarios-sao-as-maiores-vitimas-de-doencasosteomusculares-e-do-tecido-conjuntivo>. Acesso em: 17 nov. 2012.

SOARES, L. R.; VILLELA, W. V. O assédio moral na perspectiva de bancários. Revista Brasileira de Saúde Ocupacional, São Paulo, v. 37, n. 126, p. 203-212, 2012.

SZNELWAR, L. I.; MASSETI, M. Agressóes ao corpo e/ ou sofrimento psíquico? Um estudo construído a partir da experiência de trabalhadores com LER/DORT. Travailler, Paris, v. 2, n. 8, p. 159-176, 2002.

SZNELWAR, L. I.; UCHIDA, S.; LANCMAN, S. A subjetividade no trabalho em questão. Tempo Social, São Paulo, v. 23, n. 1, p. 11-30, 2011.

WATANABE, M.; NICOLAU, S. M. A Terapia Ocupacional na interface da saúde e do trabalho. In: DE CARLO, M. M. R.; BARTALOTTI, C. C. (Org.). Terapia Ocupacional no Brasil. São Paulo: Plexus, 2001. p. $155-172$.

\section{Contribuição dos Autores}

Camilla de Paula Zavarizzi participou do projeto, da obtenção, análise e discussão dos dados, além da elaboração e revisão do manuscrito. Maria do Carmo Baracho de Alencar coordenou e orientou a pesquisa, participando da análise, discussão e interpretação dos dados, além da elaboração e revisão do manuscrito. 